\title{
Rancang Bangun Aplikasi E-register International Conference Berbasis Online Pada Universitas Lancang Kuning
}

\author{
Bayu Febriadi ${ }^{*}$, Pandu Pratama Putra ${ }^{2}$ \\ ${ }_{1}^{1}$ Program Studi Sistem Informasi Fakultas Ilmu Komputer Universitas Lancang Kuning \\ ${ }^{2}$ STMIK AMIK Riau \\ e-mail: bayufebriadi9@gmail.com*, pandupratamaputra91@gmail.com
}

\begin{abstract}
Computer-based information systems are very influential in the world of work, as well as webbased information systems are used as a means of information enhancement. Utilization will facilitate a job as well as faster data processing, the decision to be taken more precisely, saving time and cost. Because the needs of the yellowish university to realize the vision and mission must be in line with the activities undertaken, one of them by producing a paper or a scientific paper lecturer who indexed such as scopus and thompson, so the yellowish university held an international Conference held in cooperation with other universities, both domestic and foreign, this requires a media or information that can be accessed by lecturers in the country and abroad in terms of registration of scientific work to be on international Conference activities with online-based. In the international Conference that will be held university of lancang kuning no media that can be used as a means to promote, because this is considered very important for the achievement of the purpose of international Conference activities to be implemented. The method used by collecting existing data and analyzing problems in the collection and adjustment of Paper International Conference. The general purpose of this research is to build an E-register paper application to make it easier for users to register papers for seminars at youthful university.
\end{abstract}

Keywords: International Conference, Information System, online.

\begin{abstract}
Abstrak
Sistem Informasi berbasis komputer sangat berpengaruh pesat dalam dunia kerja, begitu juga halnya sistem informasi berbasis web dimanfaatkan sebagai sarana peningkatan informasi. Pemanfaatan tersebut akan mempermudah suatu pekerjaan seperti halnya pengolahan data lebih cepat, keputusan yang akan diambil lebih tepat, menghemat waktu dan biaya. Berhubung kebutuhan universitas lancang kuning untuk mewujudkan visi dan misi harus sejalan dengan kegiatan yang dilakukan, salah satunya dengan menghasilkan paper atau pun karya ilmiah dosen yang terindeks seperti scopus dan thompson, sehingga universitas lancang kuning mengadakan international Conference yang diadakan dengan kerja sama dengan universitas lain, baik dalam dan luar negeri, hal ini membutuhkan suatu media atau informasi yang bisa di akses oleh dosen-dosen yang ada di dalam negeri maupun luar negeri dalam hal pendaftaran karya ilmiahnya supaya bisa diseminarkan pada kegiatan international Conference dengan berbasis online. Dalam kegiatan international Conference yang akan dilaksanakan universitas lancang kuning belum adanya media yang bisa digunakan sebagai sarana untuk mempromosikan, karena hal ini dirasa sangat penting demi tercapainya tujuan dari kegiatan international Conference yang akan dilaksanakan. Adapun metode yang digunakan dengan mengumpulkan data-data yang ada dan menganalisa permasalahan dalam pengumpulan dan penyesuaian Paper International Conference. Tujuan umum dari penelitian ini untuk membangun aplikasi E-register Paper sehingga memudahkan user mendaftarkan paper untuk diseminarkan pada universitas lancang kuning.
\end{abstract}

Kata kunci: International Conference, Sistem Informasi, Online 


\section{PENDAHULUAN}

Penggunaan sistem informasi berbasis komputer yang dapat diakses melalui internet dapat dimanfaatkan untuk sarana peningkatan informasi di era revolusi industri 4.0 sehingga keputusan dapat diambil dengan dengan cepat karena pengolahan data yang tepat dan menghemat biaya dan waktu. Dalam dunia akademik penggunaan salah satsistem informasi adalah pelaksanaan kegiatan conference. Conference merupakan istilah yang mempunyai makna suatu kegiatan pertemuan antara sekelompok orang, negarawan, usahawan, dan sebagainya, untuk membahas masalah-masalah yang berkaitan dengan kepentingan bersama yang tertuang dalam SK menteri nomor : KM 108/HM. 703/MPPT-91. Sementara artikel/ paper/ makalah merupakan naskah utuh dan sistematik yang berisikan outlines permasalah yang diselesaikan dengan beberapa pendekatan keilmuan tertentu baik berupa uraian pendapat, gagasan maupun pembahasan dalam rangka pemecahan masalah. Sementara International Conference merupakan seminar yang dilaksanakan oleh P2KK LIPI dengan skala internasional. P2KK-LIPI dapat bekerjasama dengan beberapa instansi dalam menyelenggarakan seminar internasional yang dihadiri oleh para peneliti dari lingkungan LIPI, instansi dalam dan luar negeri, serta masyarakat umum yang berkumpul dan membahas permasalah lewat artikel yang dibuat berdasarkan topik permasalahan yang diangkat.

Penelitian sebelumnya yang membahas tentang pendaftaran seminar artikel berbasis web oleh Angga P. Dewandi, yang membahas bagaimana memanfaatkan tenologi dalam mempermudah kegiatan seminar yang akan dilakukan sehingga dengan penerapan aplikasi berbasis komputerisasi membantu dalam pengolahan data, dengan penelitian tersebut penulis mengembangkan untuk melakukan pengembangan aplikasi berbasis online dalam pendafataran artikel yang disebut dalam kegiatan seminar international Icetech dan Ichas 2017 yang diadakan oleh universitas lancang kuning dengan bekerjasama dengan universitas lainya.

Berhubung kebutuhan universitas lancang kuning untuk mewujudkan visi dan misi harus sejalan dengan kegiatan yang dilakukan, salah satu mengadakan kegiatan international Conference dengan menghasilkan paper atau pun karya ilmiah dosen yang terindeks seperti scopus dan thompson, sehingga universitas lancang kuning mengadakan international Conference yang diadakan dengan kerja sama dengan universitas lain, baik dalam dan luar negeri, sehingga hal ini membutuhkan suatu media atau informasi yang bisa di akses oleh dosen-dosen yang ada di dalam negeri maupun luar negeri dalam hal pendaftaran karya ilmiahnya supaya bisa diseminarkan pada kegiatan international Conference dengan berbasis online. Dalam kegiatan international Conference yang akan dilaksanakan universitas lancang kuning, belum adanya media yang bisa digunakan sebagai sarana untuk mempromosikan dan sebagai pendaftaran karya ilmiah yang akan diseminarkan, karena hal ini dirasa sangat penting demi tercapainya tujuan dari kegiatan international Conference yang akan dilaksanakan. 


\section{METODE PENELITIAN}

Dalam artikel ini menggunakan metode pengumpulan data dan metode pengembangan sistem sebagai berikut :

\subsection{Metode Pengumpulan Data}
a. Metode Kepustakaan
b. Metode Observasi
c. Metode Wawancara

\subsection{Metode Pengembangan Sistem}

Tahapan utama siklus pengembangan sistem adalah: metode pengembangan terstruktur dengan pendekatan System Development Life Cycle atau SDLC yang terdiri:

a. Perencanaan (Planning)

b. Analisa Sistem (System Analysis)

c. Perancangan Sistem (System design)

d. Implementasi Sistem (System Implementation)

e. Operasi dan pemeliharaan sistem (System operation and maintenance).

\subsection{Alat dan Teknik Pengembangan Sistem}

Alat yang digunakan dalam suatu metodologi dapat berupa gambar/ diagram/ grafik agar mudah dimengerti. Berikut Alat-alat pengembangan sistem yang berbentuk grafik diantaranya :
a. Diagram Hierarchy plus Input-Proces-Output,
b. Diagram aliran data (Data Flow diagram).
c. Diagram keterhubungan (Entity Relationship Diagram).
d. Diagram Perubahan status (State Transition Diagram).
e. Structured Chart.

\section{HASIL DAN PEMBAHASAN}

\subsection{Rancangan sistem yang baru}

Penulis merancang suatu sistem dengan menggunakan metode pengembangan sistem development lyfe cycle dengan alat perancangan sistem pendekatan unified modelling language (UML).

\section{a. Usecase Diagram}

Usecase Diagram menjelaskan gambaran actor-aktor yang terlibat dalam penggunaan sistem yang akan dibangun, dapat dilihat pada gambar dibawah ini: 


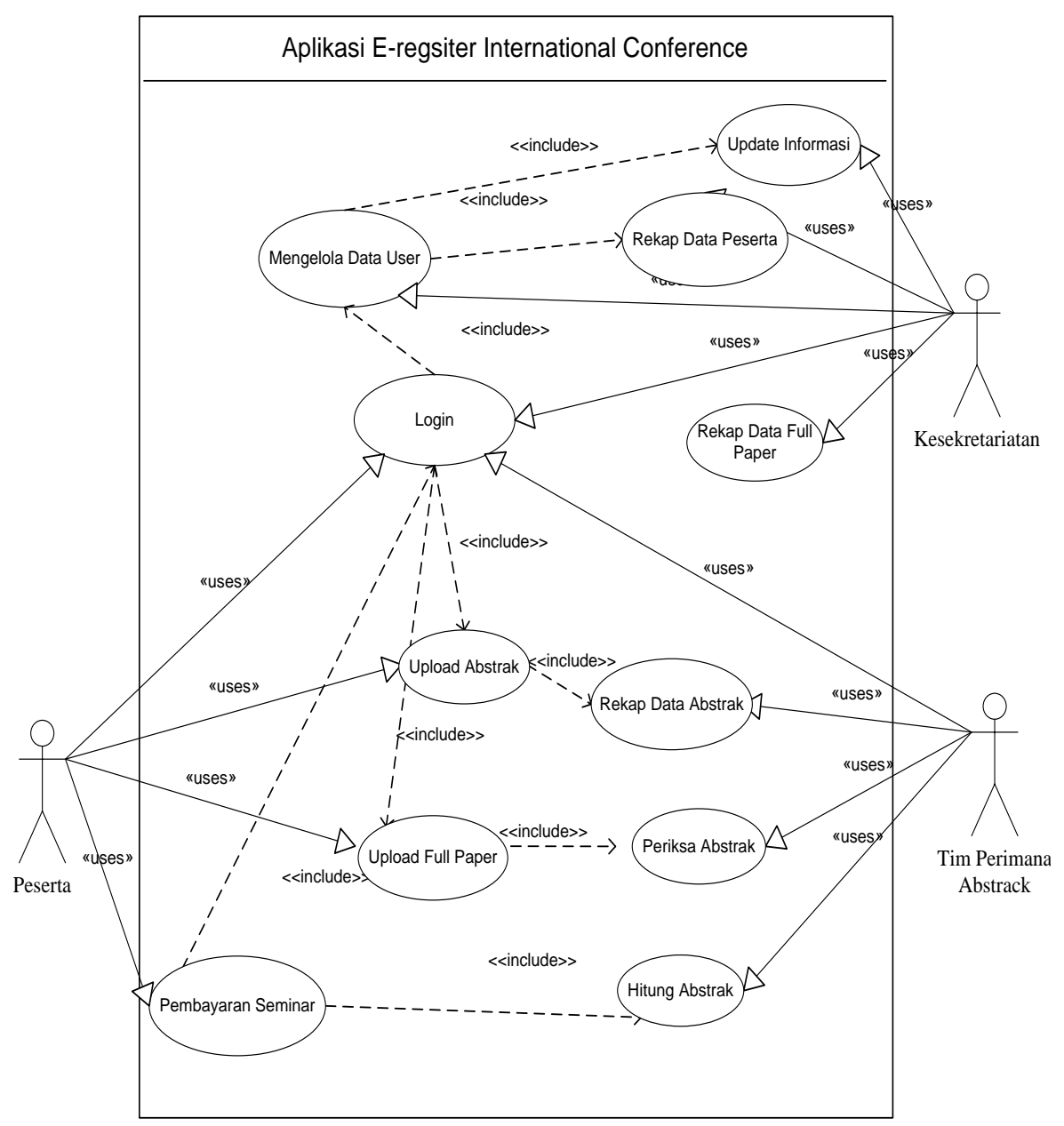

Gambar 1. Usecase Diagram

Dalam pengembangan sistem ada 3 aktor yaitu: Peserta Seminar, Kesekretariatan dan Tim Penerima Abstrak. Pertama bagian kesekretariatan bertugas mengontrol sistem, mengisi content, mengelola akun pengguna sistem, maintenance aplikasi dalam pengumpulan full paper dari peserta seminar, sehingga tim penerima abstrak merekap data abstrak ke seminar dan memeriksa abstrak apakah sudah sesuai. Setelah itu peserta seminar melakukan pengiriman data abstrak dan full paper, lalu melakukan pembayaran biaya seminar.

\section{b. Activity Diagram}

Activity Diagram menjelaskan bagaimana alur dari sistem yang dikembangkan dalam register peserta international onference berbasis online pada universitas lancang kuning, dapat dilihat pada gambar berikut: 


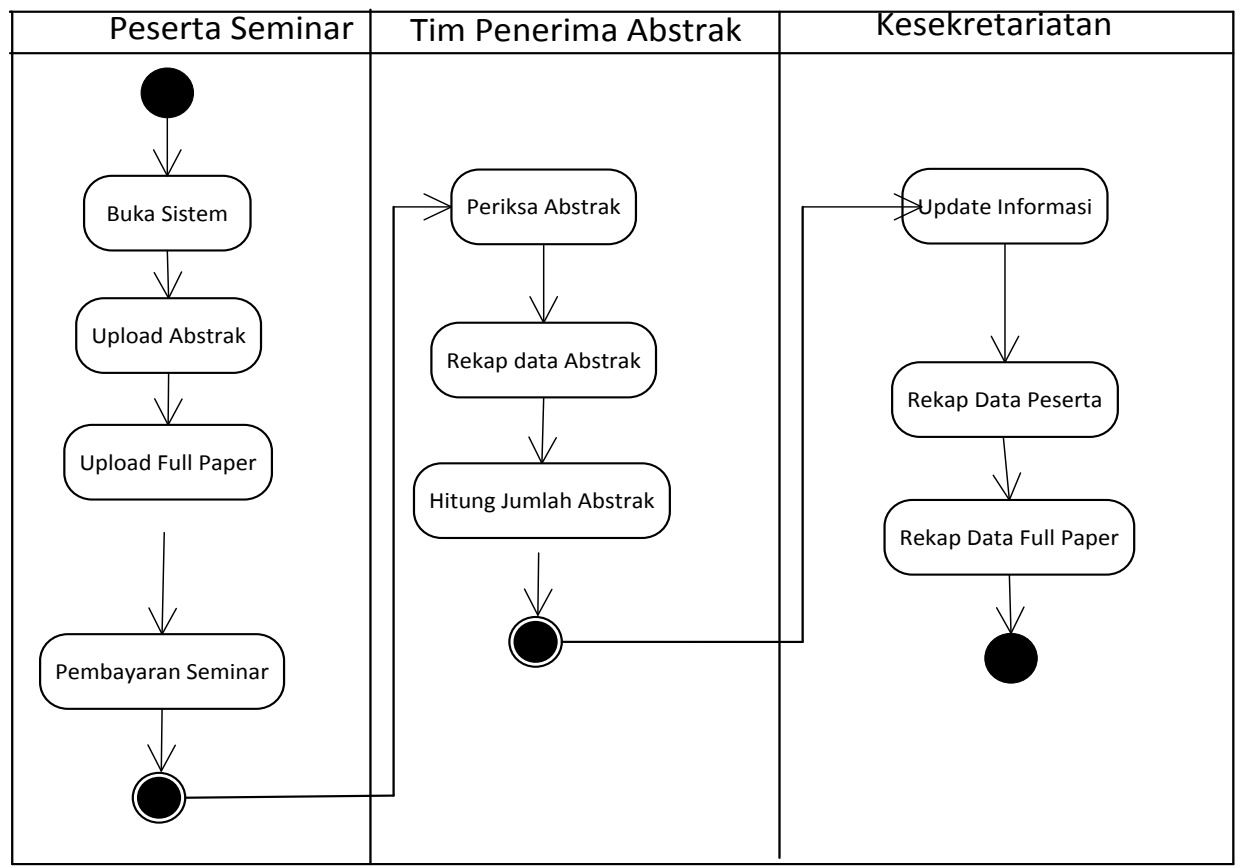

Gambar 2. Activity Diagram

Pada activity diagram menjelaskan alur dosen dalam pendaftaran international Conference sistem yang berbasis online. Peserta seminar juga membaca dan melihat panduan dalam pembuatan Paper lalu mengirim full paper ke sistem dan melakukan pembayaran seminar. Lalu tim penerima abstrak mengontrol apakah abstrak dan full paper yang mendaftar sudah sesuai format atau belum.

\section{c. Class Diagram}

Class Diagram menjelaskan entitas dan atribut didalam sistem Eregister international Conference, dapat dilihat pada gambar $\underline{3}$ di bawah ni:

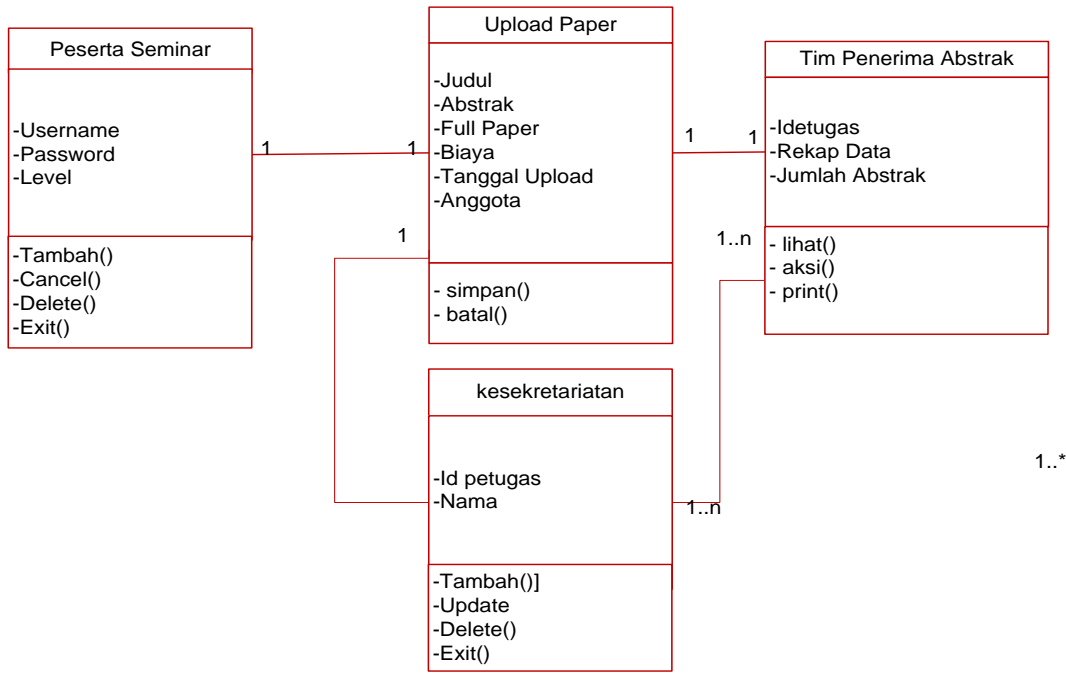

Gambar 3. Class Diagram 
Pada class diagram ada 4 entitas dalam sistem E-register international Conference: Login, upload paper, Tim penerima Abstrak, dan Kesekretariatan.

\subsection{Interface sistem yang baru}

Pada tampilan sitem yang baru yang telah dibangun berdasarkan perancangan sebelumnya dari pemodelan unified modelling language (UML) yang terdiri dari usecase diagram, activity diagram, dan class diagram.

\section{a. Menu Utama}

Pada rancangam sistem yang dibangun menu utama aplikasi E-register international Conference pada Universitas Lancang

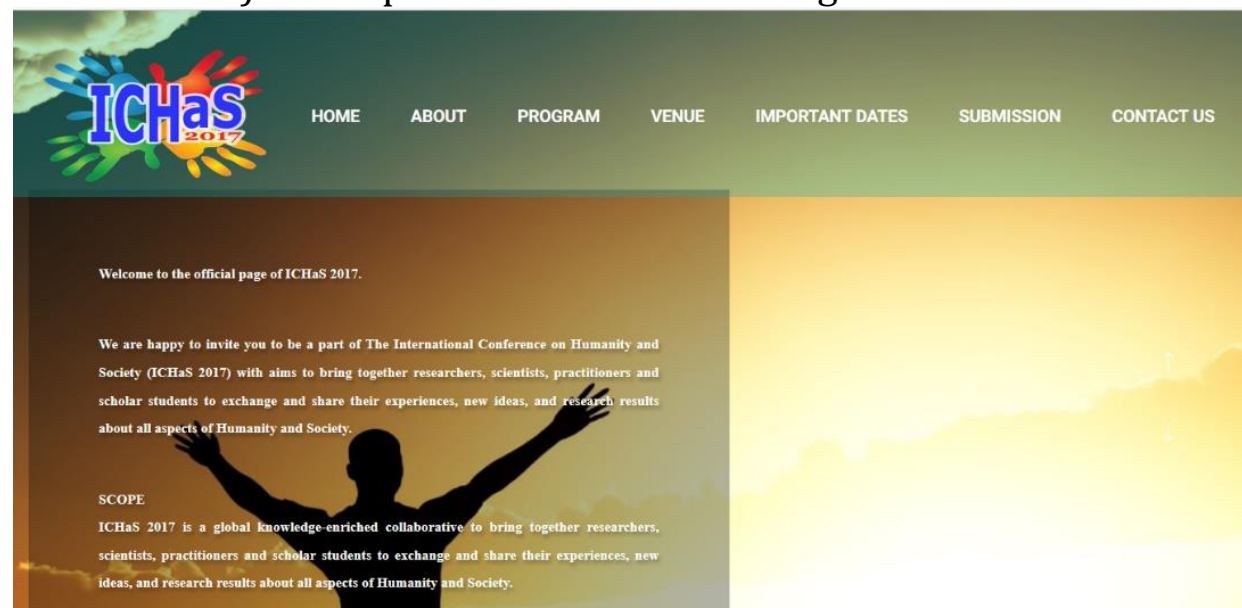

Gambar 4. Tampilan Menu Utama

\section{b. Registrasi}

Pada rancangan sistem yang dibangun menu registrasi aplikasi $E$ register international Conference pada Universitas Lancang Kuning dapat dilihat pada gambar dibawah ini.

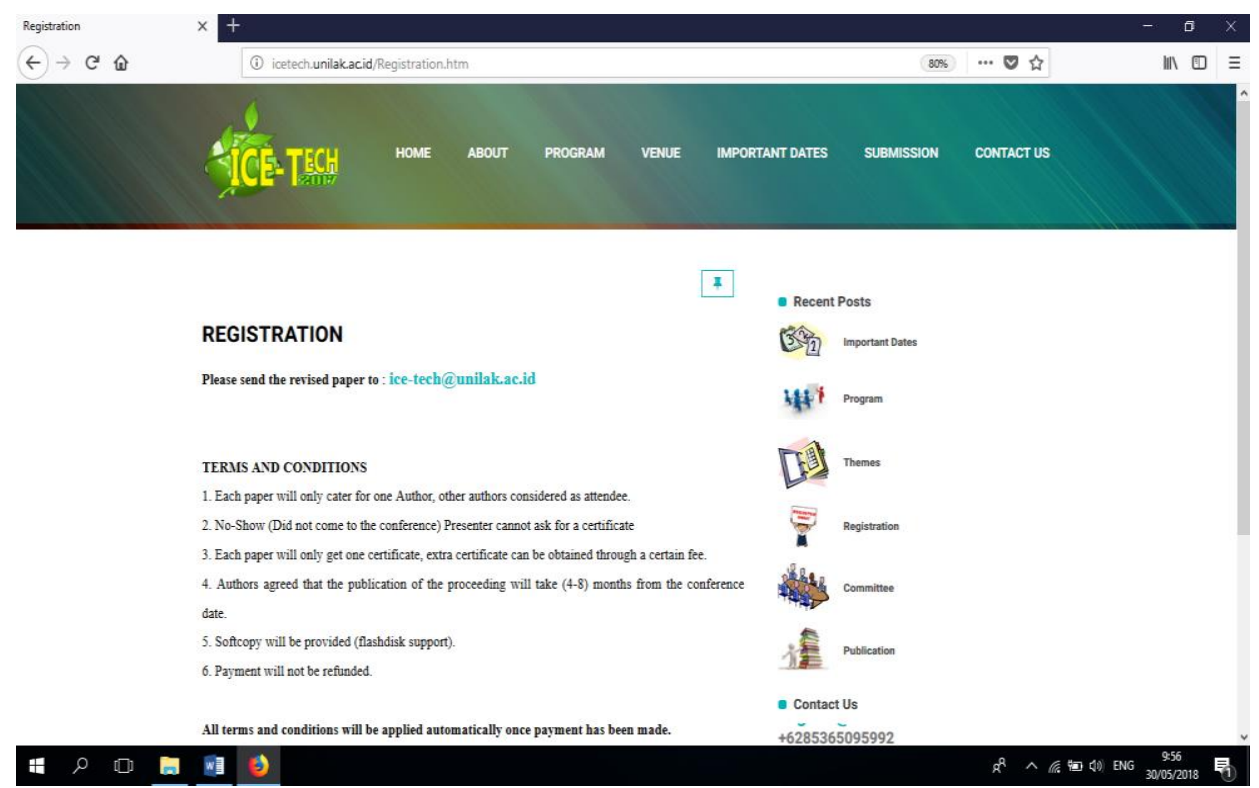

Gambar 5. Tampilan Menu Registrasi 


\section{c. Venue}

Pada rancangan sistem yang dibangun menu venue aplikasi E-register international Conference pada Universitas Lancang Kuning dapat dilihat pada gambar dibawah ini.

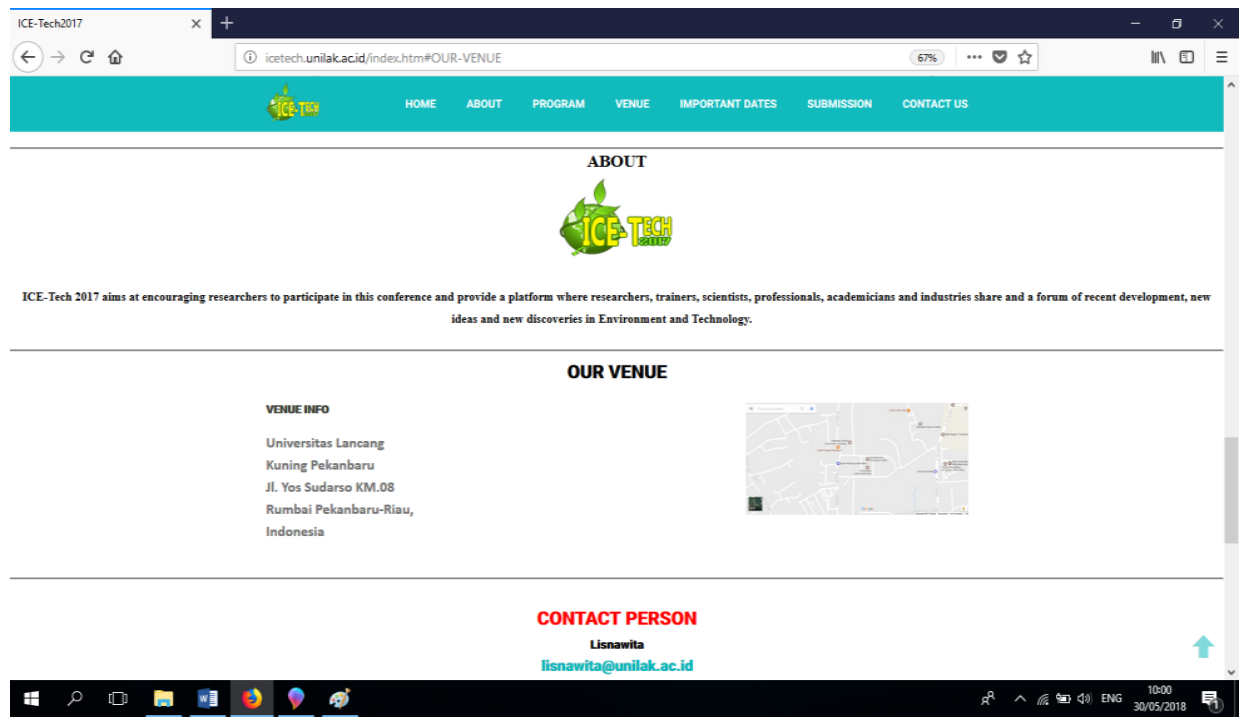

Gambar 6. Tampilan Menu Venue

\section{d. Program}

Pada rancangan sistem yang dibangun menu program kegiatan aplikasi E-register international Conference pada Universitas Lancang Kuning dapat dilihat pada gambar dibawah ini.

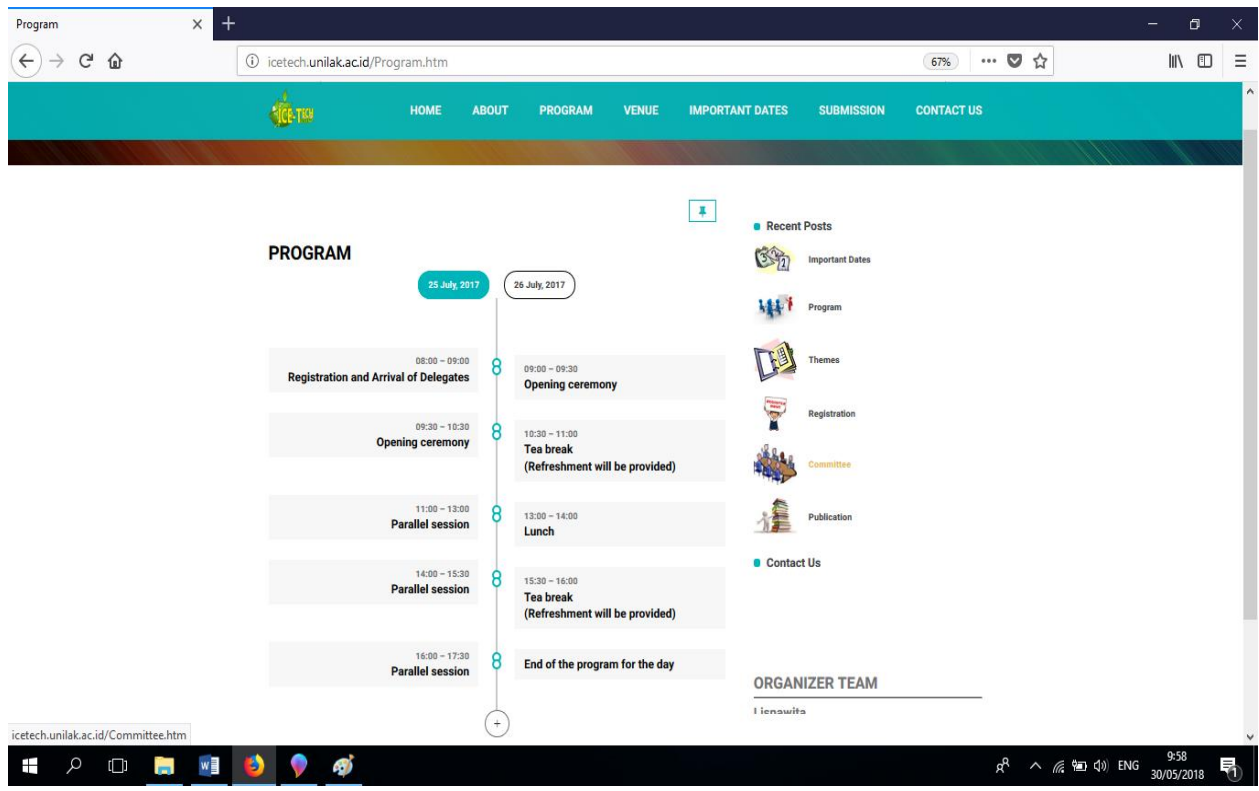

Gambar 7. Tampilan Menu Program 


\section{e. Theme}

Pada rancangan sistem yang dibangun menu Theme aplikasi E-register international Conference pada Universitas Lancang Kuning dapat dilihat pada gambar dibawah ini.

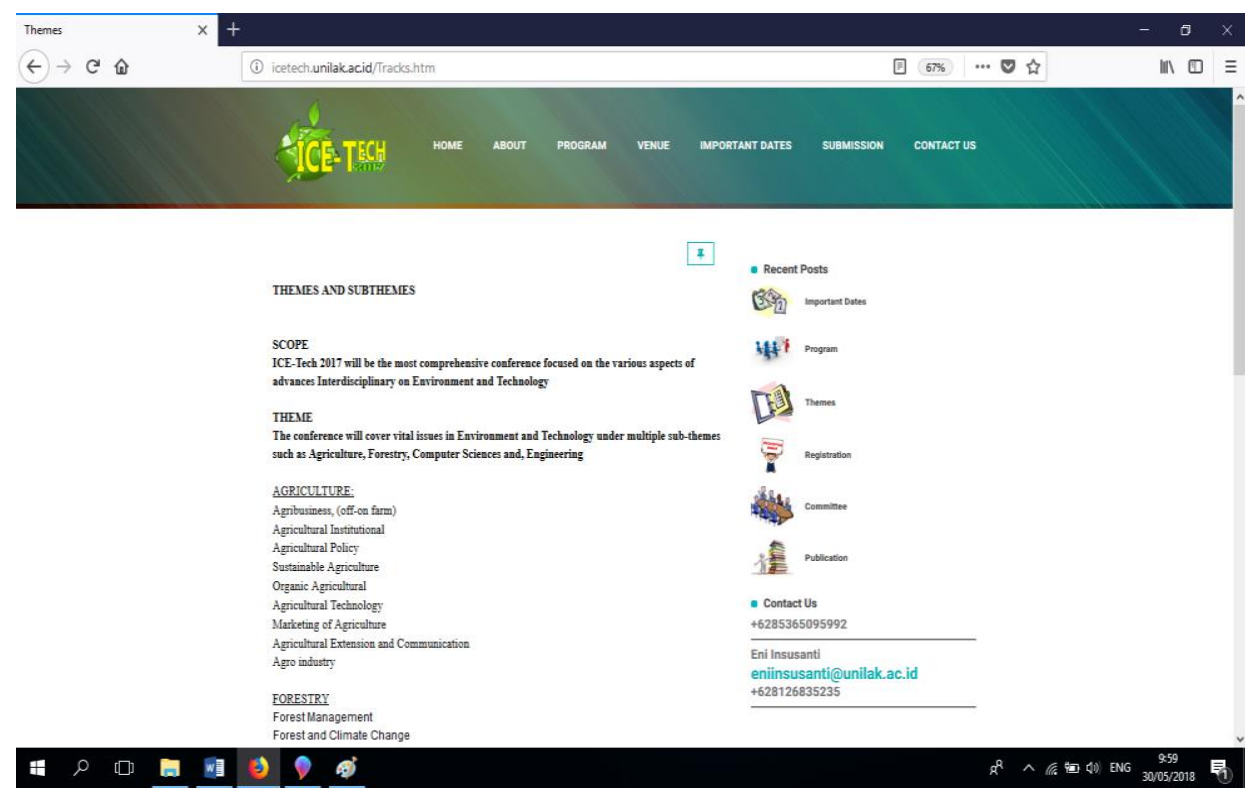

Gambar 8. Tampilan Menu Theme

\section{f. Submission}

Pada rancangan sistem yang dibangun menu submission aplikasi $E$ register international Conference pada Universitas Lancang Kuning dapat dilihat pada gambar dibawah ini.

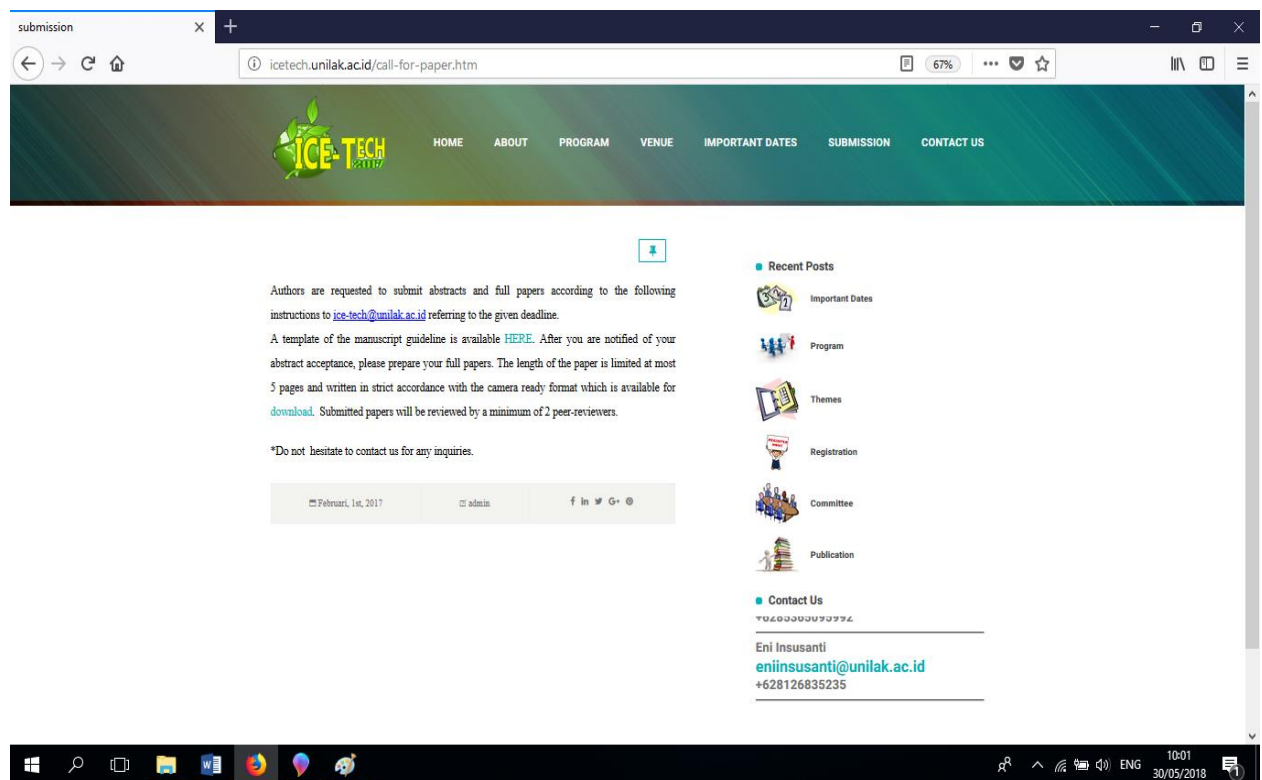

Gambar 9. Tampilan Menu Submission 


\section{g. Call Of Paper}

Pada rancangan sistem yang dibangun menu Call Of Paper aplikasi Eregister international Conference pada Universitas Lancang Kuning dapat dilihat pada gambar dibawah ini.
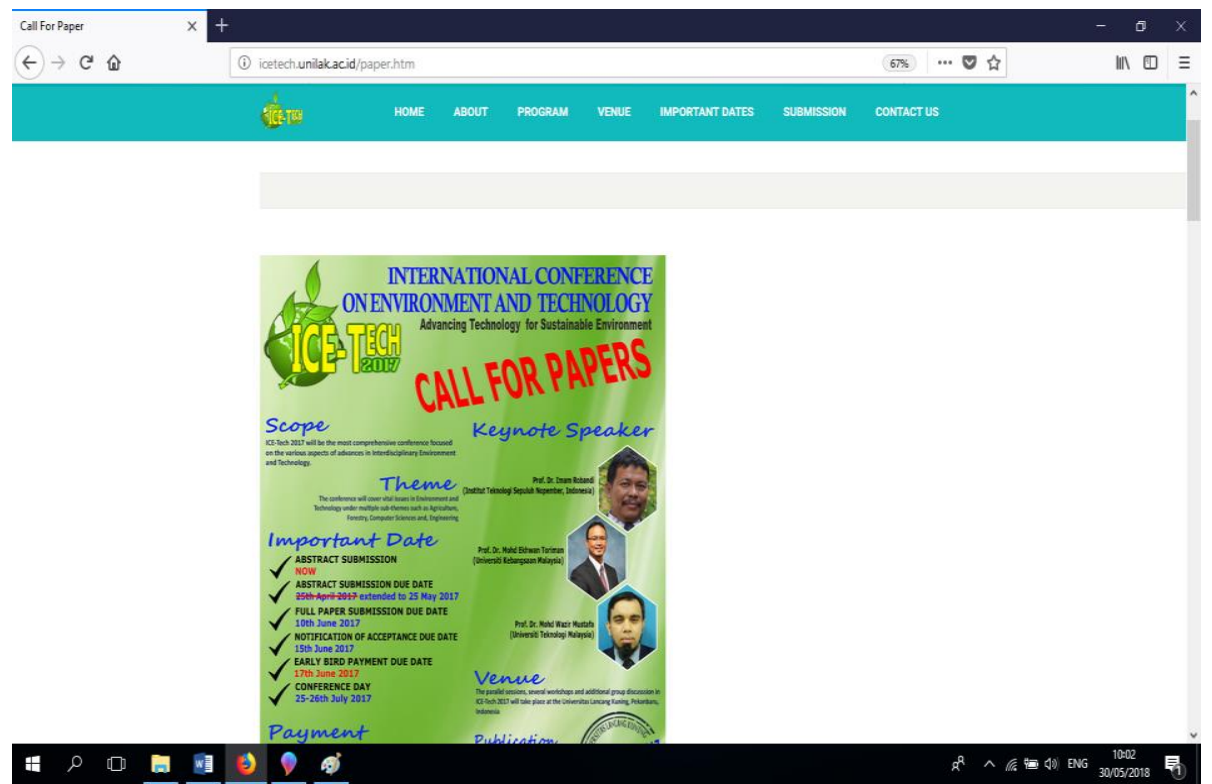

Gambar 10. Tampilan Menu Call Of Paper

\section{SIMPULAN}

Setelah dilakukan kegiatan penelitian pada universitas lancang kuning, maka penulis menyimpulkan bahwa kegiatan paper international Conference sangat membantu universitas lancang kuning dalam membantu registry paper dan mempromosikan kegiatan sehingga jumlah paper yang mendaftar lebih banyak karena dapat diakses dimana dan kapan saja.

\section{DAFTAR PUSTAKA}

[1] ANISYA, A., \& Hidayat, W. (2017). Analisa Perancangan Aplikasi Pengolahan Data Akademik Berbasis Web. Jurnal TeknoIf ISSN 2338-2724, 5(2).

[2] Febriadi, Bayu (2017). Efisiensi Sistem Informasi Berbasis Online Dalam Pengumpulan Rpkps Mata Kuliah Untuk Pengembangan Kompetensi Program Studi. Journal: Teknologi Informasi dan Komunikasi, Digital Zone ISSN 24773255.

[3] Hardjono. 2006. Pengenalan Sistem Informasi Berbasis Web. Jakarta: Erlangga

[4] Herawati, Y. (2013). Rekayasa Perangkat Lunak Untuk Penjualan Perlengkapan Pengantin Adat Minangkabau Berbasis Web. Padang: Institut Teknologi Padang

[5] Kadir, Abdul. 2005. Pengenalan Sistem Informasi. Jakarta, Yogyakarta: Andi

[6] Mohammad Yazdi, 2012, e-learning sebagai media pembelajaran interaktif berbasis teknologi informasi, urnal Ilmiah Foristek Vol. 2, No. 1, Maret 2012, Fakultas Matematika dan Ilmu Pengetahuan Alam, Universitas Tadulako. 
[7] Nyimas Sriwihajriyah, 2012, Perancangan aplikasi E-Profile berbasis online sebagai sarana informasi dosen pada stmik pusri Palembang, Jurnal Sistem Informasi (JSI), VOL. 4, NO. 1, April 2012.

[8] Oneto, Erima. 2008. Cascading Management Style Sebagai media Program Berbasis Web. Bandung: Informatika

[9] Pratama, Ferdian Aditya. 2014. Penerapan Teknologi Google Cloud Messaging Service Sebagai Pengiriman Push Notification pada Aplikasi Mobile Commerce Berbasis Android. Salatiga: Jurusan Teknik Informatika Universitas Kristen Satya Wacana.

[10] Saraswati, E. (Volume 2 No 4 - Oktober 2013, ISSN: 2302-5700). Sistem Informasi Akademik Berbasis Web Pada Sekolah Menengah Pertama Negeri 3 Pringkuku. Indonesian Journal On Networking and Security - IJNS.

[11] Sutabri, Tata. 2005. Sistem Informasi Managemen. Jakarta: Andi Jogja 